\title{
The effects of a caffeine-containing beverage on muscle explosiveness during ballistic bench throws
}

Emily Kammerer, Tyler Krings, Stephanie Wojton, Elizabeth Scheckel, Eric Kuklinski, Kelsey Jacobs, Carly Homan, Jenna Veldhuizen, Stephen Siegle, Amanda Wright, Meghan McCann, Dawn Anderson, Lonnie Lowery*

From International Society of Sports Nutrition: 9th Annual ISSN Conference and Expo

Clearwater, FL, USA. 22-23 June 2012

\section{Background}

There is limited information available regarding the effects of caffeine-containing drinks on high intensity exercise performance. We hypothesized that Redline ${ }^{\mathbb{R}}$ energy drink would significantly increase $(\mathrm{p}<0.05)$ muscle explosiveness in bench throws (BT) when compared to an identical placebo (PLB) in recreationally fit subjects $(n=16)$.

\section{Methods}

After a day of dietary control and caffeine abstinence, otherwise fasted subjects performed four individual ballistic bench throws under two conditions (Redline ${ }^{\circledR}$, PLB), with trials being separated by 48-96 hours. The peak force (FOR), peak power (POW), peak velocity (VEL), peak displacement (DSP), and maximum rate of force development (RFD) of the Redline ${ }^{\circledR}$ trial were compared to PLB.

\section{Results}

Early results suggest a significant increase in FOR (Redline ${ }^{\mathbb{B}} 329.6 \pm 108.8 \mathrm{~N}$ vs. PLB $322.9 \pm 107.1 \mathrm{~N}$ [p=0.015]); POW (Redline ${ }^{\circledR} 468 \pm 177 \mathrm{~W}$ vs. PLB $446 \pm 175 \mathrm{~W}[\mathrm{p}=$ $0.001]$ ); and VEL (Redline ${ }^{\circledR} 1.82 \pm 0.18 \mathrm{~m} / \mathrm{s}$ vs. PLB $1.76 \pm$ $0.19 \mathrm{~m} / \mathrm{s}[\mathrm{p}=0.0035])$; and a trend in the data $(\mathrm{p}<0.10)$ for DSP (Redline ${ }^{\circledR} 0.92 \pm 0.08 \mathrm{~m}$ vs. PLB $0.90 \pm .10 \mathrm{~m}[\mathrm{p}=$ $.0665]$ ); and RFD (Redline ${ }^{\circledR} 529 \pm 262 \mathrm{~N} / \mathrm{s}$ vs. PLB $493 \pm$ $219 \mathrm{~N} / \mathrm{s}$ [p=0.0685]).

* Correspondence: lowerylm@mountunion.edu

Department of Health, Exercise and Rehabilitative Sciences, Winona State University, Winona, MN 55987, USA

\section{() Biomed Central}

\section{Conclusions}

These preliminary data supported our hypothesis that muscle explosiveness in the bench throw would increase under the influence of Redline ${ }^{\circledR}$ energy drink.

Published: 19 November 2012

\section{doi:10.1186/1550-2783-9-S1-P15}

Cite this article as: Kammerer et al:: The effects of a caffeine-containing beverage on muscle explosiveness during ballistic bench throws. Journal of the International Society of Sports Nutrition 2012 9(Suppl 1):P15.
Submit your next manuscript to BioMed Central and take full advantage of:

- Convenient online submission

- Thorough peer review

- No space constraints or color figure charges

- Immediate publication on acceptance

- Inclusion in PubMed, CAS, Scopus and Google Scholar

- Research which is freely available for redistribution

Submit your manuscript at www.biomedcentral.com/submit
() Biomed Central 